\title{
Reversible NO Motion in Crystalline [Fe(Porph)(1-Melm)(NO)] Derivatives
}

\author{
Nathan J. Silvernail ${ }^{\dagger}$, Jeffrey W. Pavlik ${ }^{\dagger}$, Bruce C. Noll ${ }^{\dagger}$, Charles E. Schulz ${ }^{\ddagger}$, and W. Robert \\ Scheidt ${ }^{\star}, \dagger$ \\ $\dagger$ University of Notre Dame \\ $\$$ Knox College
}

\section{Abstract}

The synthesis, characterization, and X-ray structures of three low-spin (nitrosyl)iron(II) tetraarylporphyrinates, $[\mathrm{Fe}(\mathrm{T} p \mathrm{XPP})(\mathrm{NO})(1-\mathrm{MeIm})]$, where $\mathrm{X}=\mathrm{F}$ (in a triclinic and a monoclinic form) and $\mathrm{OCH}_{3}$ are reported. All three molecules, at $100 \mathrm{~K}$, have a single orientation of NO. These structures are the first examples of ordered NO's in [Fe(Porph)(NO)(1-MeIm)] complexes. The three new derivatives have similar structural features including a previously unnoted "bowing" of the $\mathrm{N}_{\mathrm{NO}}-\mathrm{Fe}-\mathrm{N}_{\mathrm{Im}}$ angle caused by a concerted tilting of the axial $\mathrm{Fe}-\mathrm{N}_{\mathrm{NO}}$ and $\mathrm{Fe}-\mathrm{N}_{\mathrm{Im}}$ bonds. Structural features such as the displacement of $\mathrm{Fe}$ out of the mean porphyrin plane toward NO, tilting of the $\mathrm{Fe}-\mathrm{N}_{\mathrm{NO}}$ bond off the heme normal, and the asymmetry of the $\mathrm{Fe}-\mathrm{N}_{\text {por }}$ bonds further strengthen and confirm observations from earlier studies. The $[\mathrm{Fe}(\mathrm{T} p \mathrm{XPP})(\mathrm{NO})(1-\mathrm{MeIm})]$ complexes were also studied at temperatures between $125-350 \mathrm{~K}$ to investigate temperature-dependent variations and trends in the coordination group geometry. At varying temperatures (above $150 \mathrm{~K}$ ), all three derivatives display a second orientation of the NO ligand. The population and depopulation of this second orientation is thermally driven, with no apparent hysteresis. Crystal packing appears to be the significant feature in defining the order/disorder of the NO ligand. The length of the bond trans to $\mathrm{NO}, \mathrm{Fe}-\mathrm{N}_{\mathrm{Im}}$, was also found to be sensitive to temperature variation. The $\mathrm{Fe}-\mathrm{N}_{\mathrm{Im}}$ bond length increases with increased temperature, whereas no other bonds change appreciably. The T-dependent $\mathrm{Fe}-\mathrm{N}_{\text {Im }}$ bond length change and cell volume changes are consistent with a "soft" $\mathrm{Fe}-\mathrm{N}_{\text {Im }}$ bond. Variable temperature measurements show that the $\mathrm{N}-\mathrm{O}$ stretching frequency changes with the $\mathrm{Fe}-$ $\mathrm{N}_{\mathrm{Im}}$ bond length. Temperature-dependent changes in the $\mathrm{Fe}-\mathrm{N}_{\mathrm{Im}}$ bond length and $\mathrm{N}-\mathrm{O}$ stretching frequency were also found to be completely reversible with no apparent hysteresis.

\section{Introduction}

Nitric oxide (NO) coordination to heme proteins has many physiological consequences. It has been implicated in a number of fundamental processes including smooth muscle relaxation, 1,2 platelet deaggregation, ${ }^{3}$ neuronal communication, ${ }^{4}$ aspects of myocardial function, and numerous other physiological functions. ${ }^{5} \mathrm{NO}$ is synthesized by nitric oxide synthase by a hemezsmediated oxidation of L-arginine ${ }^{6-8}$ or from $\mathrm{NO}_{3}^{-} / \mathrm{NO}_{2}^{-} .9$ In many heme proteins the NO ligand is coordinated trans to a histidine ligand. ${ }^{10,11}$ Coordination of NO to the fivecoordinate, high-spin iron(II) results in a spin transition to low spin, movement of the iron center from $\sim 0.30-0.40$ Å out-of-plane to a position in the heme plane, and causes an elongation

*To whom correspondence should be addressed: E-mail Scheidt.1@nd.edu, Fax (574) 631-4044.

Contribution from the Department of Chemistry and Biochemistry, University of Notre Dame, Notre Dame, Indiana 46556 and

Department of Physics, Knox College Galesburg, Illinois, 61401 
of the Fe-His( $\mathrm{Im})$ bond. Modulation of the length of this bond is thought to have important biological implications. $10,11,12$

The NO ligand imparts a strong trans effect that can cause the rupture of the $\mathrm{Fe}-\mathrm{His}$ bond in a number of protein systems to give five-coordinate $\{\mathrm{FeNO}\}^{7}$ systems, $10,13,14$ whereas in others, upon NO binding the heme remains a six-coordinate $\{\text { FeNO }\}^{7}$ system. ${ }^{13}, 15$ This is the activation "switch" in one example of an NO sensing protein, sGC ${ }^{16}$ — with an apparent rupture of the Fe-His bond. ${ }^{12}$ Structural changes induced by the elongation and eventual scission of this bond are believed to be essential in signal transduction in endothelial cells, ultimately leading to vasodilatation. 10,17

The strength of the Fe-His(Im) bond in five-coordinate hemes has been used as a gauge of protein ligation and activation states, and as a possible predictor of protein activity. The FeHis $(\mathrm{Im})$ bond strength in five-coordinate hemes is readily studied with vibrational spectroscopy. $13,18,19$ Unfortunately, much less information is available about the Fe-His (Im) bond in six-coordinate iron(II) hemes with diatomic ligands that would provide information on details of, for example, control of ligand binding. Some insight into the nature of the $\mathrm{Fe}-\mathrm{His}(\mathrm{Im})$ bond post ligand ejection has been attained through flash photolysis experiments with MbXO and HbXO. ${ }^{18,20}$ Additional vibrational information has come from nuclear resonance vibrational spectroscopy (NRVS). ${ }^{21}$ This experimental technique, combined with theoretical investigations, has provided significant new information on the nature of the Fe-His(Im) vibrational modes in the $\left[\mathrm{Fe}^{\mathrm{II}}(\right.$ Porph $\left.)(\mathrm{RIm})(\mathrm{XO})\right]$ systems. ${ }^{22,23,} 24$

The power of these NRVS studies has stimulated us to further synthesize and characterize a number of new [Fe $\left.{ }^{\mathrm{II}}(\mathrm{Porph})(\mathrm{RIm})(\mathrm{XO})\right]$ complexes for such studies. In addition, this preparative and characterization work has had some interesting and unanticipated benefits. Small molecule X-ray diffraction studies, for example, have demonstrated changes in the iron coordination chemistry between $\left[\mathrm{Fe}^{\mathrm{II}}(\mathrm{Porph})(\mathrm{NO})\right]$ and $\left[\mathrm{Fe}^{\mathrm{II}}(\mathrm{Porph})(\mathrm{RIm})(\mathrm{NO})\right]$ systems. $^{25}$ Detailed structural and vibrational correlation in ligand bonding parameters (the inverse $\mathrm{Fe}-$ $\mathrm{C}$ and $\mathrm{C}-\mathrm{O}$ relationship) have been made for $\left[\mathrm{Fe}^{\mathrm{II}}(\mathrm{Porph})(\mathrm{RIm})(\mathrm{CO})\right]$ systems. ${ }^{26}$ In this paper, we report the synthesis and characterization of a series of [Fe $\left.{ }^{\mathrm{II}}(\mathrm{Porph})(1-\mathrm{MeIm})(\mathrm{NO})\right]$ complexes. The analyses of their molecular structures, over a range of temperatures, has provided interesting information on the nature of the motion of the axial NO ligand in the solid state. Moreover, the Fe-His( $\mathrm{Im}$ ) interaction displays temperature-dependent behavior that can be monitored by both molecular structure determinations and variable-temperature infrared spectroscopy.

\section{Experimental Section}

\section{General Information}

All reactions were carried out under anaerobic conditions. Chloroform (Fisher), 1-propanol (Acros) and 1-methylimidazole (Acros) were used as received. Nitric oxide (Mittler Specialty Gases) was purified by passing it through a trap containing $4 \AA$ molecular sieves immersed in an ethanol/dry ice slurry. ${ }^{27}$ Free base porphyrins $\left[\mathrm{H}_{2}\right.$ Porph] were prepared according to Adler et al. ${ }^{28}[\mathrm{Fe}(\mathrm{Porph})(\mathrm{Cl})]$ was prepared according to the metalation procedure of Adler et al. ${ }^{29}$

\section{Synthesis of [Fe(Porph)(NO)(1-Melm)]}

The $[\mathrm{Fe}(\mathrm{Porph})(\mathrm{NO})(1-\mathrm{MeIm})]$ derivatives $\left(\mathrm{Porph}=\mathrm{T} p \mathrm{FPP}\right.$ or $\left.\mathrm{T} p \mathrm{OCH}_{3} \mathrm{PP}\right)$ were prepared using modifications of a previously reported synthesis. ${ }^{25}$ Approximately $30 \mathrm{mg}$ of [Fe(Porph) (Cl)] was placed into a $10 \mathrm{~mL}$ beaker along with $3 \mathrm{~mL}$ of chloroform and $3 \mathrm{~mL}$ of 1 methylimidazole. This beaker was then placed into a crystallization jar along with $0.5 \mathrm{~mL}$ of 1-propanol, $2 \mathrm{~mL}$ of chloroform and $3 \mathrm{~mL}$ of 1-methylimidazole, then subsequently sealed 
with a rubber stopper. The system was purged with Ar for 10 min and $\mathrm{NO}$ was bubbled through the inner and outer solutions for $10 \mathrm{~min}$. High quality crystals were obtained after 3 weeks.

\section{X-Ray Crystallographic Studies}

$\mathrm{X}$-ray diffraction data were collected and integrated using a Bruker $\mathrm{x} 8$ or D8 Apex II system, with graphite-monochromated Mo K $\alpha(\lambda=0.71073 \AA$ ) radiation from $100-350 \mathrm{~K}$ (700 Series Oxford Cryostream). The Oxford control unit is calibrated at the factory using the phase change of Rochelle's salt at $109 \mathrm{~K} .{ }^{30}$ The factory calibration was checked in our laboratory with an iron-constantan thermocouple and an Omega 199 temperature meter. All reported temperatures are believed accurate to within $2 \mathrm{~K}$. The programs SADABS ${ }^{31}$ and TWINABS ${ }^{32}$ were applied for absorption correction. All structures were solved using the Patterson method in $\mathrm{XS}^{33}$ and refined using XL. ${ }^{34}$ All atoms were found after successive full-matrix least-squares refinement cycles on $F^{2}$ and refined with anisotropic thermal parameters. Hydrogen atoms were placed at calculated geometries and allowed to ride on the position of the parent atom. Hydrogen thermal parameters were set to $1.2 \times$ the equivalent isotropic $\mathrm{U}$ of the parent atom and $1.5 \times$ for methyl hydrogen atoms.

Complete crystallographic details are given in the Supporting Information. Data sets were acquired at multiple temperatures for each of the six-coordinate $\mathrm{NO}$ complexes. mono-[Fe $(\mathrm{T} p \mathrm{FPP})(\mathrm{NO})(1-\mathrm{MeIm})]$, at 150 and $293 \mathrm{~K}$, contains a second orientation of $\mathrm{NO}$ oxygen which has been refined with thermal parameters equal to the first orientation. ${ }^{35}$ tri-[Fe(TpFPP)(NO) (1-MeIm)] contains a second orientation of NO oxygen in data acquired at 200, 224, 293 and $350 \mathrm{~K}$. Data was acquired on a second triclinic crystal of [Fe(TpFPP)(NO)(1-MeIm)] which contained two twinned components related by a $180^{\circ}$ rotation (minor component $\approx 20 \%$ ). This second example of the triclinic form also contained a second orientation of $\mathrm{NO}$ oxygen in data acquired at 224 and $293 \mathrm{~K}$. [ Fe( $\left.\left.\mathrm{T} p \mathrm{OCH}_{3} \mathrm{PP}\right)(\mathrm{NO})(1-\mathrm{MeIm})\right]$ contains a second orientation of $\mathrm{NO}$ oxygen in data acquired at 293 and $330 \mathrm{~K}$. Each of the $\left[\mathrm{Fe}\left(\mathrm{T} p \mathrm{OCH}_{3} \mathrm{PP}\right)(\mathrm{NO})(1-\mathrm{MeIm})\right]$ structures contain a disordered para-methoxy group modeled as two positions and modest rotational disorder of the 1-methylimidazole ligand that was left unmodeled. 36

\section{Infrared Measurements}

Infrared spectra were taken on a Nicolet Nexus 670 FT-IR spectrometer. Selected single crystals were ground/mixed minimally with $\mathrm{KBr}$ (50:1) to avoid loss of 1-methylimidazole ligand. The $\mathrm{KBr}$ pellet was placed in a Specac variable temperature cell with an Omega Engineering CN310 Solid State Temperature Controller and evacuated to a pressure of 0.1 mbar. The variable temperature cell was then placed in the Nicolet Nexus 670 FT-IR spectrometer and spectra were taken in both ascending and descending $20 \mathrm{~K}$ intervals in the range of 107 to $348 \mathrm{~K}$.

\section{Results}

The crystal and molecular structures of three six-coordinate NO iron(II) porphyrinates have been obtained at multiple temperatures between $100 \mathrm{~K}$ and $350 \mathrm{~K}$ and with several crystalline specimens. [Fe(T $p \mathrm{FPP})(\mathrm{NO})(1-\mathrm{MeIm})]$ was found to exist as two crystalline polymorphs: a monoclinic denoted mono-[Fe(T $p \mathrm{FPP})(\mathrm{NO})(1-\mathrm{MeIm})]$ and a triclinic form denoted tri-[Fe $(\mathrm{T} p \mathrm{FPP})(\mathrm{NO})(1-\mathrm{MeIm})]$. The $\left[\mathrm{Fe}\left(\mathrm{T} p \mathrm{OCH}_{3} \mathrm{PP}\right)(\mathrm{NO})(1-\mathrm{MeIm})\right]$ derivative was also studied. Cell parameters and crystallographic data for 18 distinct and completed measurements are summarized in Table 1. Detailed crystallographic data is presented in Tables S1-S108.

Temperature-dependent infrared spectra were taken between $105 \mathrm{~K}$ and $350 \mathrm{~K}$ for $[\mathrm{Fe}-$ $\left.\left(\mathrm{T} p \mathrm{OCH}_{3} \mathrm{PP}\right)(\mathrm{NO})(1-\mathrm{MeIm})\right]$, tri-[Fe(TpFPP)(NO)(1-MeIm)], and mono-[Fe(TpFPP)(NO) 
(1-MeIm)]. Experiments were performed in both ascending and descending temperature order with no indication of hysteresis.

\section{Discussion}

The structural and vibrational parameters of three complexes, [Fe(Porph)(1-MeIm)(NO)], differing only in the para-substituent of the four aryl groups, display temperature-dependent variations. Moreover, the variation of these systems displays apparent reversibility with no detectable hysteresis.

\section{Molecular Structures - $100 \mathrm{~K}$}

We report the crystal and molecular structures of the three iron(II) porphyrinates: $t r i$-[Fe (T $p$ FPP)(NO)(1-MeIm)], ${ }^{37}$ mono-[Fe(T $p$ FPP)(NO)(1-MeIm)], and [Fe(Tp $\left.\mathrm{OCH}_{3} \mathrm{PP}\right)(\mathrm{NO})(1-$ MeIm)]. The molecular structures, at $100 \mathrm{~K}$, are illustrated in Figure 1. The nitrosyl ligand is completely ordered in all three derivatives; these are the first examples of completely ordered nitrosyls in six-coordinate [Fe(Porph)(NO)(1-MeIm)] complexes. The three new derivatives have similar structural features. Selected geometrical parameters are given in Table 2. For comparison, the only example of the related iron(III) derivative ${ }^{38}$ is also given in the table. Two independent determinations of structure at $100 \mathrm{~K}$ were carried out for tri-[Fe(TpFPP) $(\mathrm{NO})(1-\mathrm{MeIm})]$ and $\left[\mathrm{Fe}\left(\mathrm{T} p \mathrm{OCH}_{3} \mathrm{PP}\right)(\mathrm{NO})(1-\mathrm{MeIm})\right]$; the averaged values for the two determinations will be cited. The observed values for the $\mathrm{Fe}-\mathrm{N}_{\mathrm{NO}}$ bond distance, the $\mathrm{N}-\mathrm{O}$ bond distance and the $\mathrm{Fe}-\mathrm{N}-\mathrm{O}$ bond angle are all similar. Values for tri-[Fe(TpFPP)(NO)(1-MeIm)], mono-[Fe(T $p \mathrm{FPP})(\mathrm{NO})(1-\mathrm{MeIm})]$ and $\left[\mathrm{Fe}\left(\mathrm{T} p \mathrm{OCH}_{3} \mathrm{PP}\right)(\mathrm{NO})(1-\mathrm{MeIm})\right]$, respectively are: 1.7481(11) $\AA, 1.756(5)$ (ave.), and 1.751(3) (ave.) for the $\mathrm{Fe}-\mathrm{N}_{\mathrm{NO}}$ bond distance; 1.1808(14) $\AA, 1.183(2)$ (ave.), and 1.188(3) (ave.) for the $\mathrm{N}-\mathrm{O}$ bond distance; and $137.27(9)^{\circ}, 138.4(4)^{\circ}$ (ave.), and $136.0(2)^{\circ}$ (ave.) for the $\mathrm{Fe}-\mathrm{N}-\mathrm{O}$ bond angle.

Several additional features of six-coordinate $\{\mathrm{FeNO}\}^{7}$ porphyrinates are summarized in the formal core diagrams given in Figure 2. One feature is the displacement of the $\mathrm{Fe}$ from the 24atom mean plane. In all cases there is a small $(0.05-0.08 \AA)$ displacement towards the NO ligand. The projection of the $\mathrm{Fe}-\mathrm{N}_{\mathrm{NO}}$ vector onto the porphyrin plane is displayed in Figure 2 as the short line; the small circle represents the oxygen position. The projection of the imidazole onto the porphyrin plane is displayed in Figure 2 as the long line; the large circle represents the position of the 1-methyl group. The projection of $\mathrm{Fe}-\mathrm{N}_{\mathrm{NO}}$ is close to bisecting a pair of $\mathrm{Fe}-\mathrm{N}_{\mathrm{p}}$ bonds; the actual values and the angle between the $\mathrm{FeNO}$ and imidazole planes are also shown in the figure.

As can be seen in Figure 1, the $\mathrm{Fe}-\mathrm{N}_{\mathrm{NO}}$ vector is tilted off-axis from the heme normal in the direction of the NO oxygen atom. The tilts for mono-[Fe(TpFPP)(NO)(1-MeIm)], tri-[Fe $(\mathrm{T} p \mathrm{FPP})(\mathrm{NO})(1-\mathrm{MeIm})]$ and $\left[\mathrm{Fe}-\left(\mathrm{T} p \mathrm{OCH}_{3} \mathrm{PP}\right)(\mathrm{NO})(1-\mathrm{MeIm})\right]$ are $7.1^{\circ}, 4.8(3)^{\circ}$; (ave. $)$ and 5.0 $(1)^{\circ}$; (ave.), respectively. This tilt appears to be a direct effect of the FeNO bonding; we find no steric reasons for the tilts. Moreover, this tilt is associated with an asymmetry in the equatorial $\mathrm{Fe}-\mathrm{N}_{\mathrm{p}}$ bonds. The two $\mathrm{Fe}-\mathrm{N}_{\mathrm{p}}$ bonds that bracket the NO ligand are shorter than the average whereas the other two are longer. This asymmetry is clearly a bonding effect. Porphyrin core asymmetry is also observed in five-coordinate $\{\mathrm{FeNO}\}^{7}$ porphyrinates. ${ }^{39}$ For the complexes mono-[Fe(TpFPP)(NO)(1-MeIm)], tri-[Fe(TpFPP)(NO)(1-MeIm)], and [Fe $\left.\left(\mathrm{T} p \mathrm{OCH}_{3} \mathrm{PP}\right)(\mathrm{NO})(1-\mathrm{MeIm})\right]$ respectively, the two short $\mathrm{Fe}-\mathrm{Np}$ bonds are: 1.992(4) $\AA$, 2.003 (2) $\AA$ (ave.), and 1.996(10) $\AA$ (ave.); while the long Fe-Np bonds are: 2.011(11) $\AA, 2.017$ (3) $\AA$ (ave.), and 2.017(5) $\AA$ (ave.), respectively. Since the first experimental elaboration of the tilt and equatorial asymmetry, a number of DFT calculations $40,41,42,43,44$ have provided an electronic basis for ligand-based asymmetry. 
The Fe- $\mathrm{N}_{\text {Im }}$ bond is also tilted off-axis, but by smaller amounts. Moreover, as can be seen in Figure 1, the imidazole tilt and the NO tilt are toward each other so as to lead to a "bowing" in the $\mathrm{N}_{\mathrm{NO}}-\mathrm{Fe}-\mathrm{N}_{\text {Im }}$ bond angle. "Bowing" of the $\mathrm{N}_{\mathrm{NO}}-\mathrm{Fe}-\mathrm{N}_{\text {Im }}$ unit is not unique to these porphyrinates. Although it has not been noted previously, this feature is general to all sixcoordinate $\{\mathrm{FeNO}\}^{7}$ porphyrinates; it is also observed in $[\mathrm{Fe}(\mathrm{TPP})(\mathrm{NO})(1-\mathrm{MeIm})],{ }^{25,45}[\mathrm{Fe}$ $\left.(\mathrm{TPP})(\mathrm{NO})\left(4-\mathrm{NMe}_{2} \mathrm{Py}\right)\right]^{25}$ and $\left[\mathrm{Fe}\left(\mathrm{To} \mathrm{F}_{2} \mathrm{PP}\right)(\mathrm{NO})(1-\mathrm{MeIm})\right]^{40}$

A saddling pattern is observed for the core 24-atoms of tri-[Fe(TpFPP)(NO)(1-MeIm)] and mono-[Fe(TpFPP)(NO)(1-MeIm)], while in $\left[\mathrm{Fe}\left(\mathrm{T} p \mathrm{OCH}_{3} \mathrm{PP}\right)(\mathrm{NO})(1-\mathrm{MeIm})\right]$ the core is only modestly ruffled. Saddling is a commonly observed core conformation of six-coordinate iron (II) porphyrinates with a single axial diatomic ligand. Saddled cores have been observed in [Fe (TPP)(NO)(1-MeIm)], ${ }^{25}$ [Fe(TPP)(NO)(4-NMe $\left.2 \mathrm{Py}\right]^{25}$ and [Fe(TPP)(NO)(4-MePip)]. ${ }^{25}$

The structures of these three six-coordinate $\{\mathrm{FeNO}\}^{7}$ porphyrinates further strengthen and confirm observations made during earlier studies. ${ }^{25,40,45}$ Wyllie et al. suggested a best set of structural parameters for six-coordinate $\{\mathrm{FeNO}\}^{7}$ porphyrinates. ${ }^{25}$ With the inclusion of the additional points presented herein, the canonical values for the bonding parameters of sixcoordinate $\{\mathrm{FeNO}\}^{7}$ porphyrinates with imidazole ligation may now be even more firmly assigned. Selected average structural parameters and standard deviations 46 for [Fe(Porph) (NO)(1-MeIm)] are given in Figure 3. Data include the five $100 \mathrm{~K}$ structures presented herein and two previous structure determinations. 25,40 The range of bond lengths for each of the bonding parameters is small, with the exception of the Fe- $\mathrm{N}_{\text {Im }}$ bond which is known to be very long owing to the structural trans effect of NO. The average values of bonding parameters agree well with those presented previously as general parameters for six-coordinate $\{\mathrm{FeNO}\}$ 7 porphyrinates, ${ }^{25}$ yet give additional information due to the multiple data collections and the high precision of the data.

\section{Molecular Structures - Multiple Temperatures}

A "fortuitous" failure of the crystal cooling system led to the collection of a data set for tri-[Fe $(\mathrm{T} p \mathrm{FPP})(\mathrm{NO})(1-\mathrm{MeIm})]$ at room temperature. The structure revealed two orientations of the NO ligand; a disordered NO is common with many prior examples. $25,40,45,47$ Upon repair of the cryocooler, the structure was redetermined at $100 \mathrm{~K}$. The same crystalline sample now showed a single orientation of the NO ligand at the lower temperature. This suggests that the second orientation of $\mathrm{NO}$ in $\operatorname{tri}-[\mathrm{Fe}(\mathrm{T} p \mathrm{FPP})(\mathrm{NO})(1-\mathrm{MeIm})]$ is a temperature-dependent phenomenon. Accordingly, we collected a number of additional data sets at different temperatures and on two crystal samples for tri-[Fe(TpFPP)(NO)(1-MeIm)]. ${ }^{48,49}$ A total of ten distinct data sets were collected; the order of data collections are indicated in Table 3 . The graphical depiction in Figure 4 shows experiment order, experiment temperature, NO orientations and the population of the major NO orientation. Several generalizations are apparent from the figure for tri-[Fe(TpFPP)(NO)(1-MeIm)]. First, at low temperature the NO ligand is ordered for two different crystal samples. Second, similar populations of the NO orientation are observed at the same temperature. Third, the population of the second orientation increases with increasing temperature. Fourth, the order/disorder of NO is a thermally driven, reversible process. Finally, the results appear to be sample independent, although in this experiment and the others following have been necessarily limited to two samples each.

A smaller set of temperature-dependent structure determinations were subsequently made for mono-[Fe(TpFPP)(NO)(1-MeIm)] and [Fe(Tp $\left.\left.\mathrm{OCH}_{3} \mathrm{PP}\right)(\mathrm{NO})(1-\mathrm{MeIm})\right] .50$ Again, temperature-dependent NO orientational disorder was observed. The experimental order given in Table 3 also shows apparent reversibility of the NO orientation. At room temperature, two orientations of NO were found in both complexes. However, at lower temperatures, each of the two samples contains only a single orientation of the NO ligand. 
These three studies allow for the observation of possible temperature-dependent variations or trends in the coordination group geometry of $\{\mathrm{FeNO}\}^{7}$ porphyrinates. Bond lengths, angles and other geometrical parameters for the coordination group are given in Table 3 . The metrical parameters show little or no temperature dependence. Although a second orientation of the NO becomes evident at higher temperatures, the absolute and relative orientations of the imidazole and the major NO orientation do not show any temperature dependence. Formal core diagrams of all derivatives at all measured temperatures are given in Figures S1, S2 and S3 that show this invariance as well as only very small differences in core conformations. The Fe- $\mathrm{N}_{\mathrm{Im}}$ distance and the $\mathrm{Fe}-\mathrm{N}_{\mathrm{NO}}$ tilt angle show the largest temperature-dependent effect.

Tilting of the Fe- $\mathrm{N}_{\mathrm{NO}}$ vector, as described above, is an inherent characteristic of $\{\mathrm{FeNO}\}_{7}$ porphyrinates. The Fe- $\mathrm{N}_{\mathrm{NO}}$ tilt shows an apparent temperature dependence; the tilt is smaller with increased temperature. However, the true degree of temperature variation is difficult to measure due to uncertainties associated with the NO nitrogen position. The two orientations of the NO ligand lead to two positions of the nitrogen that should lead to a small change in the apparent refined position which is the average of the population-weighted positions. This, along with possible effects of increased thermal motion, lead to apparent shifts in the nitrogen position and concomitant decreases in the tilt angle that overstate the temperature-dependent change.

As displayed in Figure 3, the tilting of the $\mathrm{Fe}-\mathrm{N}_{\mathrm{NO}}$ vector in $\{\mathrm{FeNO}\}_{7}$ porphyrinates induces asymmetry in the $\mathrm{Fe}-\mathrm{N}_{\mathrm{p}}$ bonds. All of the complexes presented, at every temperature, have a similar pattern of a pair of shortened $\mathrm{Fe}-\mathrm{N}_{\mathrm{p}}$ bonds and a pair of elongated $\mathrm{Fe}-\mathrm{N}_{\mathrm{p}}$ bonds.

Average values of short and long $\mathrm{Fe}-\mathrm{N}_{\mathrm{p}}$ for tri-[Fe(TpFPP)(NO)(1-MeIm)], mono-[Fe(TpFPP) $(\mathrm{NO})(1-\mathrm{MeIm})]$ and $\left[\mathrm{Fe}\left(\mathrm{T} p \mathrm{OCH}_{3} \mathrm{PP}\right)(\mathrm{NO})(1-\mathrm{MeIm})\right]$, which contain a single ordered $\mathrm{NO}$ at $100 \mathrm{~K}$, have been calculated and are displayed in Table 3. Although variation of the $\mathrm{Fe}-\mathrm{N}_{\mathrm{p}}$ bond lengths attributed to multiple orientations should be observed, the measured differences are smaller than the uncertainties; bond asymmetry is observed in all cases.

The strong trans effect of $\mathrm{NO}$ causes the rupture of the $\mathrm{Fe}-\mathrm{His}$ bond in a number of protein systems to give five-coordinate $\{\mathrm{FeNO}\}^{7}$ systems $, 10,13,14$ while in others, upon NO binding the heme remains six-coordinate $\{\mathrm{FeNO}\}^{7} .13,15$ Clearly understanding the nature of this bond and its effects are essential to understanding heme $\{\mathrm{FeNO}\}^{7} \mathrm{NO}$-sensing systems. The activation "switch" in sGC is an apparent rupture of the Fe-His bond. ${ }^{12}$ Structural changes induced by the elongation and eventual scission of this bond are believed to be essential in signal transduction, ultimately leading to vasodilatation. 10,17

The known trans directing effect of $\mathrm{NO}$ on the $\mathrm{Fe}-\mathrm{N}_{\text {Im }}$ bond suggests that the bond might be described as "soft" and be especially susceptible to temperature-dependent environmental effects. ${ }^{51}$ This is indeed the case. The length of the biologically important $\mathrm{Fe}-\mathrm{N}_{\mathrm{Im}}$ bond in each of the three six-coordinate $\{\mathrm{FeNO}\}^{7}$ porphyrinates shows a linear dependence on temperature. Plotted in the lower panel of Figure 5 is the temperature dependence of the Fe$\mathrm{N}_{\text {Im }}$ bond for $t r i$-[Fe(TpFPP)(NO)(1-MeIm)], mono-[Fe(TpFPP)(NO)(1-MeIm)], and [Fe $\left.\left(\mathrm{T} p \mathrm{OCH}_{3} \mathrm{PP}\right)(\mathrm{NO})(1-\mathrm{MeIm})\right]$. The change in cell volume as a function of temperature is shown in the top panel of Figure 5; the correlation between changes in cell volume and the Fe- $\mathrm{N}_{\mathrm{Im}}$ bond length are evident. The change in cell volumes for the three complexes between 100 and $293 \mathrm{~K}$ is about 3.6 to $3.8 \%$. The changes in cell volume are not unusual for porphyrin complexes in our experience, although perhaps at the upper end of ranges observed. ${ }^{52}$ The change of the $\mathrm{Fe}-\mathrm{N}_{\mathrm{Im}}$ bond distance in $\left[\mathrm{Fe}\left(\mathrm{T} p \mathrm{OCH}_{3} \mathrm{PP}\right)(\mathrm{NO})(1-\mathrm{MeIm})\right](2.1659(8)-2.2030(14) \AA, 100-330$ $\mathrm{K})$, tri-[Fe(TpFPP)(NO)(1- MeIm)] (2.1669(12)-2.1934(28) $\AA$, 100-350 K) and mono-[Fe (TpFPP)(NO)(1-MeIm)] (2.1312(11)-2.158(2) $\AA, 100-293 \mathrm{~K})$ is small but unidirectional.

The effects of the temperature-dependent crystal packing on the $\mathrm{Fe}-\mathrm{N}_{\mathrm{Im}}$ is best seen in tri-[Fe $(\mathrm{T} p \mathrm{FPP})(\mathrm{NO})(1-\mathrm{MeIm})]$. Figure 6 displays the relative shift of adjacent molecules in the unit 
cell for tri-[Fe(TpFPP)(NO)(1-MeIm)] at $100 \mathrm{~K}$. In this figure, coordinates of the porphyrin nitrogen atoms of the 100 and $350 \mathrm{~K}$ structures have been overlaid for the two molecules shown at the bottom right. The relative differences in the intermolecular spacing of $\sim 0.5 \AA$ can now be seen between the $100 \mathrm{~K}$ structure (shown in blue) and the $350 \mathrm{~K}$ structure (shown in red). The contraction of the cell and the tighter intermolecular contacts in the $100 \mathrm{~K}$ structure can be clearly seen. This cell contraction is manifested in a shortening of $\mathrm{Fe}-\mathrm{N}_{\text {Im }}$ by about $0.02 \AA$. Clearly the weakness of the $\mathrm{Fe}-\mathrm{N}_{\mathrm{Im}}$ bond has contributed to the temperature dependence of the $\mathrm{Fe}-\mathrm{N}_{\mathrm{Im}}$ bond distance. The red vector shown in Figure 6 has approximately equal components in the $a$ and $b$ directions that is also seen in the relative changes in the cell constants. Although the directions are not as clear in $\left[\mathrm{Fe}\left(\mathrm{T} p \mathrm{OCH}_{3} \mathrm{PP}\right)(\mathrm{NO})(1-\mathrm{MeIm})\right]$ and mono-[Fe (T $p$ FPP)(NO)(1-MeIm)], they similarly display a shortening of the $\mathrm{Fe}-\mathrm{N}_{\mathrm{Im}}$ bond due to contraction of the unit cell and decreased intermolecular interactions with reduced temperature.

\section{Variable-Temperature Infrared Studies}

Temperature-dependent infrared data were collected for [ $\left.\mathrm{Fe}\left(\mathrm{T} p \mathrm{OCH}_{3} \mathrm{PP}\right)(\mathrm{NO})(1-\mathrm{MeIm})\right]$, tri-[Fe(TpFPP)(NO)(1-MeIm)] and mono-[Fe-(TpFPP)(NO)(1-MeIm)] at temperatures ranging from 107 to $348 \mathrm{~K}$. Infrared measurements were made to determine if the distinct NO orientations observed in the X-ray diffraction experiments would be vibrationally observable. In all three complexes, a single $v_{\mathrm{N}-\mathrm{O}}$ band was observed with no discernible broadening that might suggest a second $v_{\mathrm{N}-\mathrm{O}}$ peak. The most significant change observed was an increasing value of $v_{\mathrm{N}-\mathrm{O}}$ with increasing temperature. The temperature dependence ( 20 degree intervals) of $v_{\mathrm{N}-\mathrm{O}}$ vs. T is given in Figure 7. In all cases the change in $v_{\mathrm{N}-\mathrm{O}}$ vs. temperature demonstrates a linear dependence with high correlation.

What effect leads to the T-dependence? A theoretical study of the two polymorphic forms of $[\mathrm{Fe}(\mathrm{T} p \mathrm{FPP})(\mathrm{NO})(1-\mathrm{MeIm})]$ suggested equivalent energy-minimized structures and vibrational data despite the differences in the relative orientation of the NO and imidazole planes (i.e., cisoid and transoid). ${ }^{23}$ Thus, relative differing orientations appear not to have an effect on $v_{\mathrm{N}-\mathrm{O}}$. Rather, we believe that it is the temperature-dependent changes in the $\mathrm{Fe}-\mathrm{N}_{\mathrm{Im}}$ bond length, not any environmental differences of the NO ligand, that causes the variation of $v_{\mathrm{N}-\mathrm{O}}$ with temperature. These values are strongly correlated for each complex. Figure 8 displays a plot of the $\mathrm{Fe}-\mathrm{N}_{\mathrm{Im}}$ bond length vs. the $\mathrm{N}-\mathrm{O}$ stretching frequency for tri-[Fe(TpFPP)(NO)(1MeIm)] (red circles), mono-[Fe(TpFPP)(NO)(1-MeIm)] (blue squares) and $\left[\mathrm{Fe}\left(\mathrm{T} p \mathrm{OCH}_{3} \mathrm{PP}\right)\right.$ (NO)(1-MeIm)] (green diamonds). The two polymorphic forms of [Fe(TpFPP)(NO)(1-MeIm)] fall on the same line (best fit line in black) and demonstrate that the correlation is independent of crystalline form. Plots of $\mathrm{Fe}-\mathrm{N}_{\mathrm{Im}}$ vs. $v_{\mathrm{N}-\mathrm{O}}$ for $\left[\mathrm{Fe}\left(\mathrm{T} p \mathrm{OCH}_{3} \mathrm{PP}\right)(\mathrm{NO})(1-\mathrm{MeIm})\right]$ (green diamonds), however, do not fall onto the same line as tri-[Fe(TpFPP)(NO)(1-MeIm)] and mono-[Fe(TpFPP)(NO)(1-MeIm)]. These differences can be attributed to the cis effect of different para-substituted porphyrinates. ${ }^{55}$ The electron-donating character of the methoxysubstituent in $\left[\mathrm{Fe}\left(\mathrm{T} p \mathrm{OCH}_{3} \mathrm{PP}\right)(\mathrm{NO})(1-\mathrm{MeIm})\right]$ increases the electron density on iron thereby pushing more electron density into the SOMO and increasing the $\pi^{*}$ antibonding character of NO. This is seen experimentally in the lower $v_{\mathrm{N}-\mathrm{O}}$ frequencies observed for $\left[\mathrm{Fe}\left(\mathrm{T} p \mathrm{OCH}_{3} \mathrm{PP}\right)\right.$ (NO)(1-MeIm)]. The electron-withdrawing fluoro-substituted analog reduces electron density at the iron center thereby causing the higher observed value for $v_{\mathrm{N}-\mathrm{O}}$ in the $[\mathrm{Fe}(\mathrm{T} p \mathrm{FPP})(\mathrm{NO})$ (1-MeIm)] derivatives. Although a complete temperature profile for [Fe(TPP)(1-MeIm)(NO)] is not available, the room temperature value for the parent species is in fact at an intermediate value $\left(v_{\mathrm{N}-\mathrm{O}}=1625 \mathrm{~cm}^{-1}\right)^{45}$ consistent with its expected cis effect.

Additionally, the effect of varying the length of the $\mathrm{Fe}-\mathrm{N}_{\mathrm{Im}}$ bond is different for the two porphyrinates. As observed in Figure 8, the slope of $[\mathrm{Fe}(\mathrm{T} p \mathrm{FPP})(\mathrm{NO})(1-\mathrm{MeIm})]$ is more than $2 \times$ larger than in $\left[\mathrm{Fe}\left(\mathrm{T} p \mathrm{OCH}_{3} \mathrm{PP}\right)(\mathrm{NO})(1-\mathrm{MeIm})\right]$; the effect of changing the $\mathrm{Fe}-\mathrm{N}_{\mathrm{Im}}$ bond 
distance on $v_{\mathrm{N}-\mathrm{O}}$ is twice as large. This further reflects differences in the electronic characteristics imparted by the differing porphyrinates.

The trans effect of the heme axial ligands are thought to be of great utility to diatomic sensing heme-proteins. ${ }^{17}$ Correlations of bonding parameters across the porphyrin plane have been previously noted. ${ }^{23,47}$ The interaction between the axial ligands in heme nitrosyls are made through the SOMO. The SOMO of [Fe(Porph)(NO)(1-MeIm)] has been described as a combination of the $\pi^{*}$ orbital on $\mathrm{NO}$ and the $\mathrm{d}_{z} 2$ orbital and which is an antibonding interaction with respect to the imidazole ligand. ${ }^{40}$ A shortening in the $\mathrm{Fe}-\mathrm{N}_{\mathrm{Im}}$ bond distance must lead to (small) increases in electron donation to $\mathrm{Fe}$, which decreases the donation from the $\pi^{*}$ orbital of $\mathrm{NO}$ and a concomitant decrease in $v(\mathrm{NO})$. The converse is also possible. There has been suggestions that distal pocket interactions, steric, electronic, or both, directly influence the proximal coordination and by association signal transduction. ${ }^{15}$ The observation of spin-spin coupling between the imidazole ${ }^{14} \mathrm{~N}$ and NO observable in the EPR spectrum of [Fe(Porph) $(\mathrm{NO})(1-\mathrm{MeIm})]$ suggests at least modest interaction between the two axial ligands. 56

Mössbauer spectra have been measured in a $500 \mathrm{mT}$ field and at several temperatures. Values are given in Table 4. The values observed are similar to those observed previously for [ $\mathrm{Fe}(\mathrm{TPP})$ $(1-\mathrm{MeIm})(\mathrm{NO})]^{25}$ and are otherwise unremarkable.

\section{Summary}

Three new six-coordinate iron(II) nitrosyl-ligated porphyrinates have been prepared and characterized. At $100 \mathrm{~K}$, all structures showed an ordered nitrosyl ligand and are the first examples of completely ordered nitrosyls in [Fe(Porph)(NO)(1-MeIm)] complexes. The NO ligand is disordered at higher temperatures, this change is a reversible process. The new derivatives have similar structural features including a previously unnoted "bowing" of $\mathrm{N}_{\mathrm{NO}^{-}}$ $\mathrm{Fe}-\mathrm{N}_{\mathrm{Im}}$ caused by the concerted tilting of $\mathrm{Fe}-\mathrm{N}_{\mathrm{NO}}$ and $\mathrm{Fe}-\mathrm{N}_{\mathrm{Im}}$ bonds. The structures of these three 6-coordinate $\{\mathrm{FeNO}\}^{7}$ porphyrinates further strengthen and confirm observations made during earlier studies. X-ray diffraction experiments performed at temperatures above $100 \mathrm{~K}$ allowed the observation of temperature-dependent variations or trends in the coordination group geometry. These trends indicate a strong correlation between the physiologically relevant $\mathrm{Fe}-\mathrm{N}_{\text {Im }}$ bond and the stretching frequency of $\mathrm{NO}$ on the opposite side of the porphyrin.

\section{Supplementary Material}

Refer to Web version on PubMed Central for supplementary material.

\section{Acknowledgements}

We thank the National Institutes of Health for support of this research under Grant GM-38401 (W.R.S). We thank the NSF for X-ray instrumentation support through Grant CHE-0443233.

\section{References and Notes}

1. Rapoport RM, Murad F. Circ Res 1983;52:352. [PubMed: 6297832]

2. Ignarro LJ, Adams JB, Horwitz PM, Wood KS. J Biol Chem 1986;261:4997. [PubMed: 2870064]

3. Azuma H, Ishikawa M, Sekizaki S. Br J Pharmacol 1986;88:411. [PubMed: 3089351]Furlong B, Henderson AH, Lewis MJ, Smith JA. Br J Pharmacol 1987;90:687. [PubMed: 3495310]Radomski MW, Palmer RMJ, Moncada S. Br J Pharmacol 1987;92:639. [PubMed: 3322462]

4. Garthwaite J. Trends Neurosci 1991;14:60. [PubMed: 1708538]

5. Koshland DE Jr. Science 1992;258:1861. [PubMed: 1470903]Butler AR, Williams DLH. Chem Soc Rev 1993:233.Moncada S, Palmer RMJ, Higgs EA. Pharmacol Rev 1991;43:109. [PubMed: 1852778]

6. Marletta MA. J Biol Chem 1993;17:12231. [PubMed: 7685338] 
7. Griffth OW, Stuehr DJ. Annu Rev Physiol 1995;57:707. [PubMed: 7539994]

8. Alderton WK, Cooper CE, Knowles RG. Biochem J 2001;357:593. [PubMed: 11463332]Griffth OW, Stuehr DJ. Annu Rev Physiol 1995;57:707. [PubMed: 7539994]

9. Averill BA. Chem Rev 1996;96:2951. [PubMed: 11848847]Eich RF, Li T, Lemon DD, Doherty DH, Curry SR, Aitken JF, Mathews AJ, Johnson KA, Smith RD, Phillips GN Jr, Olson JS. Biochemistry 1996;35:6976. [PubMed: 8679521]

10. Boon EM, Marletta MA. J Inorg Biochem 2005;99:892. [PubMed: 15811506]

11. Gilles-Gonzalez MA, Gonzalez G. J Inorg Biochem 2005;99:1. [PubMed: 15598487]

12. Zhao Y, Hoganson C, Babcock GT, Marletta MA. Biochemistry 1998;37:12458. [PubMed: 9730818]

13. Schelvis JPM, Seibold SA, Cerda JF, Garavito RM, Babcock GT. J Phys Chem B 2000;104:10844.

14. Andrew CR, Kemper LJ, Busche TL, Tiwari AM, Kecskes MC, Stafford JM, Croft LC, Lu S, MöenneLoccoz P, Huston W, Moir JWB, Eady RR. Biochemistry 2005;44:8664. [PubMed: 15952773]

15. Ma X, Sayed N, Beuve A, van den Akker F. EMBO J 2007;26:578. [PubMed: 17215864]

16. The following abbreviations are used in this paper. sGC, soluble guanylate cyclase; NO, nitric oxide; mono, monoclinic; tri, triclinic; Porph, generalized porphyrin dianion; T $p$ FPP, dianion of mesopara-fluorotetraphenylporphyrin; TPP, dianion of meso-tetraphenylporphyrin; 1-MeIm, 1methylimidazole; R-Im, generalized substituted imidazole. Spectroscopic techniques: IR, infrared absorption spectroscopy; rR, resonance Raman spectroscopy; NRVS, nuclear resonance vibrational spectroscopy.

17. Stamler, JS.; Feelisch, M. Method in Nitric Oxide Research. Stamler, JS.; Feelisch, M., editors. Wiley \& Sons; New York: 1996. p. 19-27.Craven, PA.; Ignarro, LJ. Methods in Nitric Oxide Research. Stamler, JS.; Feelisch, M., editors. Wiley \& Sons; New York: 1996. p. 210-220.

18. Sage, JT.; Champion, PM. Small Substrate Recognition in Heme Proteins. In: Suslick, KS., editor. Comprehensive Supramolecular Chemistry. 5. Pergamon; Oxford, UK: 1996. p. 171-217.

19. Spiro, TG.; Li, X-Y. Resonance Raman Spectroscopy of Metalloporphyrins. In: Spiro, TT., editor. Biological Applications of Raman Spectroscopy. John Wiley \& Sons, Inc.; New York: 1988. p. 1-38.

20. Rousseau, DL.; Friedman, JM. Transient and Cryogenic Studies of Photodissociated Hemoglobin and Myoglobin. In: Spiro, TG., editor. Biological Applications of Raman Spectroscopy. John Wiley \& Sons, Inc.; New York: 1988. p. 133-216.

21. Scheidt WR, Durbin SM, Sage JT. J Inorg Biochem 2005;99:60. [PubMed: 15598492]

22. Rai BK, Durbin SM, Prohofsky EW, Sage JT, Ellison MK, Roth A, Scheidt WR, Sturhahn W, Alp EE. J Am Chem Soc 2003;125:6927. [PubMed: 12783545]

23. Silvernail NJ, Barabanschikov A, Pavlik JW, Noll BC, Zhao J, Alp EE, Sturhahn W, Sage JT, Scheidt WR. J Am Chem Soc 2007:2200. [PubMed: 17269768]

24. Leu BM, Silvernail NJ, Zgierski MZ, Wyllie GRA, Ellison MK, Scheidt WR, Zhao JY, Sturhahn W, Alp EE, Durbin SM, Sage J. Biophys J 2007;92:3764. [PubMed: 17350996]

25. Wyllie GRA, Schulz CE, Scheidt WR. Inorg Chem 2003;42:5722. [PubMed: 12950223]

26. Silvernail NJ, Roth A, Schulz CE, Noll BC, Scheidt WR. J Am Chem Soc 2005;127:14422. [PubMed: 16218637]

27. Dodd, RE.; Robinson, PL. Experimental Inorganic Chemistry. Elsevier; New York: 1957. p. 253

28. Adler AD, Longo FR, Finarelli JD, Goldmacher J, Assour J, Korsakoff L. J Org Chem 1967;32:476.

29. Adler AD, Longo FR, Kampus F, Kim J. J Inorg Nucl Chem 1970;32:2443.

30. Tomaszewski PE. Phase Trans 1992;38:127.

31. Sheldrick, GM. SADABS. Universität Göttingen; Göttingen, Germany: 2006.

32. Sheldrick, GM. TWINABS. Universität Göttingen; Göttingen, Germany: 2006.

33. Sheldrick, GM. XS. Bruker-Nonius AXS; Madison, WI: 2001. (b) Patterson AL. Phys Rev 1934;46:372.

34. Sheldrick, GM. XL. Bruker-Nonius AXS; Madison, WI: 2001.

35. Although the thermal parameters of the second orientation have been refined as equal to the first orientation, there is evidence (especially in structures above $100 \mathrm{~K}$ ) of electron density between the first and second orientations that can not be properly modeled as two or even three atoms. 
36. Attempts were made to refine the 1-methylimidazole with two rigid bodies or a disorder model with isotropic thermal parameters with no improvement to the structure.

37. An analysis of the NRVS vibrational spectra of $t r i-[\mathrm{Fe}(\mathrm{T} p \mathrm{FPP})(\mathrm{NO})(1-\mathrm{MeIm})]$ and mono-[Fe $(\mathrm{T} p \mathrm{FPP})(\mathrm{NO})(1-\mathrm{MeIm})]$ and the $100 \mathrm{~K}$ structures have been previously reported. ${ }^{23}$

38. Ellison MK, Scheidt WR. J Am Chem Soc 1999;121:5210.

39. Ellison MK, Scheidt WR. J Am Chem Soc 1997;119:7404.

40. Praneeth VKK, Näther C, Peters G, Lehnert N. Inorg Chem 2006;45:2795. [PubMed: 16562937]

41. Cheng L, Novozhilova I, Kim C, Kovalevsky A, Bagley KA, Coppens P, Richter-Addo GB. J Am Chem Soc 2000;122:7142.

42. Ghosh A, Wondimagegn T. J Am Chem Soc 2000;122:8101.Ghosh A. Acc Chem Res 2005;38:943. [PubMed: 16359166]

43. Rovira C, Kunc K, Hutter J, Ballone P, Parrinello M. J Phys Chem A 1997;101:8914.

44. Patchkovskii S, Ziegler T. Inorg Chem 2000;39:5354. [PubMed: 11154592]

45. Scheidt WR, Piciulo PL. J Am Chem Soc 1976;98:1913. [PubMed: 1254850]

46. Standard deviations are calculated on the assumption that the values are taken from the same population.

47. Scheidt WR, Brinegar AC, Ferro EB, Kirner JF. J Am Chem Soc 1977;99:7315.

48. ORTEP diagrams of $t r i$-[Fe(TpFPP)(NO)(1-MeIm)] at each reported temperature (see Table 3) are displayed in the Supporting Information.

49. During the $350 \mathrm{~K}$ data collection for $t r i$-[Fe(TpFPP)(NO)(1-MeIm)] sample decay became evident. The reported structure is based on a subset of the total reflections that represent $100 \%$ completeness to a resolution of $0.90 \AA$.

50. ORTEP diagrams of mono-[Fe(TpFPP)(NO)(1-MeIm) $]$ and $\left[\mathrm{Fe}\left(\mathrm{T} p \mathrm{OCH}_{3} \mathrm{PP}\right)(\mathrm{NO})(1-\mathrm{MeIm})\right]$ at each reported temperature (see Table 3 ) are displayed in the Supporting Information.

51. The binding constants for the addition of an imidazole to a five-coordinate nitrosyl are known to be small and are summarized in Reference 40. Neither the trans effect or the binding constant absolutely predict that the $\mathrm{Fe}-\mathrm{N}_{\mathrm{Im}}$ bond will show a strong temperature dependence.

52. For example a six-coordinate CO complex showed a 3.2\% change in cell volume. N. Sil-vernail, B. C. Noll and W. R. Scheidt, work in progress.

53. A linear correlation coefficient, Pearson's $\mathrm{R},{ }^{54}$ was used to judge the fit to the data.

$$
R=\sum_{i}\left(x_{i}-\bar{x}\right)\left(y_{i}-\bar{y}\right) / \sqrt{\sum_{i}\left(x_{i}-\bar{x}\right)^{2}} \sqrt{\sum_{i}\left(y_{i}-\bar{y}\right)^{2}}
$$

54. Walpole, RE.; Meyers, RH.; Meyers, SL.; Ye, K. Probability and Statistics for Engineers and Scientists. 7. Prentice Hall; Upper Saddle River, NJ: 2002. p. 391-394.

55. Buchler JW, Kokisch W, Smith PD. Struct Bonding (Berlin) 1978;34:79.

56. (a) Wayland BB, Olson LW. J Am Chem Soc 1974;96:6037. [PubMed: 4415859] (b) Morse RH, Chan SI. J Biol Chem 1980;255:7876. [PubMed: 6249819] 


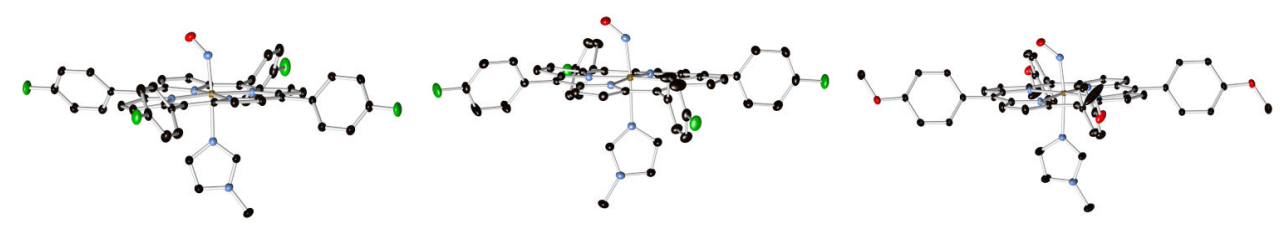

Figure 1.

ORTEP diagrams (50\% probability ellipsoids) of tri-[Fe(TpFPP)(NO)(1-MeIm)] (left), mono-[Fe(TpFPP)(NO)(1-MeIm)] (center), and [Fe(TpOCH$\left.\left.{ }_{3} \mathrm{PP}\right)(\mathrm{NO})(1-\mathrm{MeIm})\right]$ (right) at $100 \mathrm{~K}$. Hydrogen atoms are omitted for clarity. 

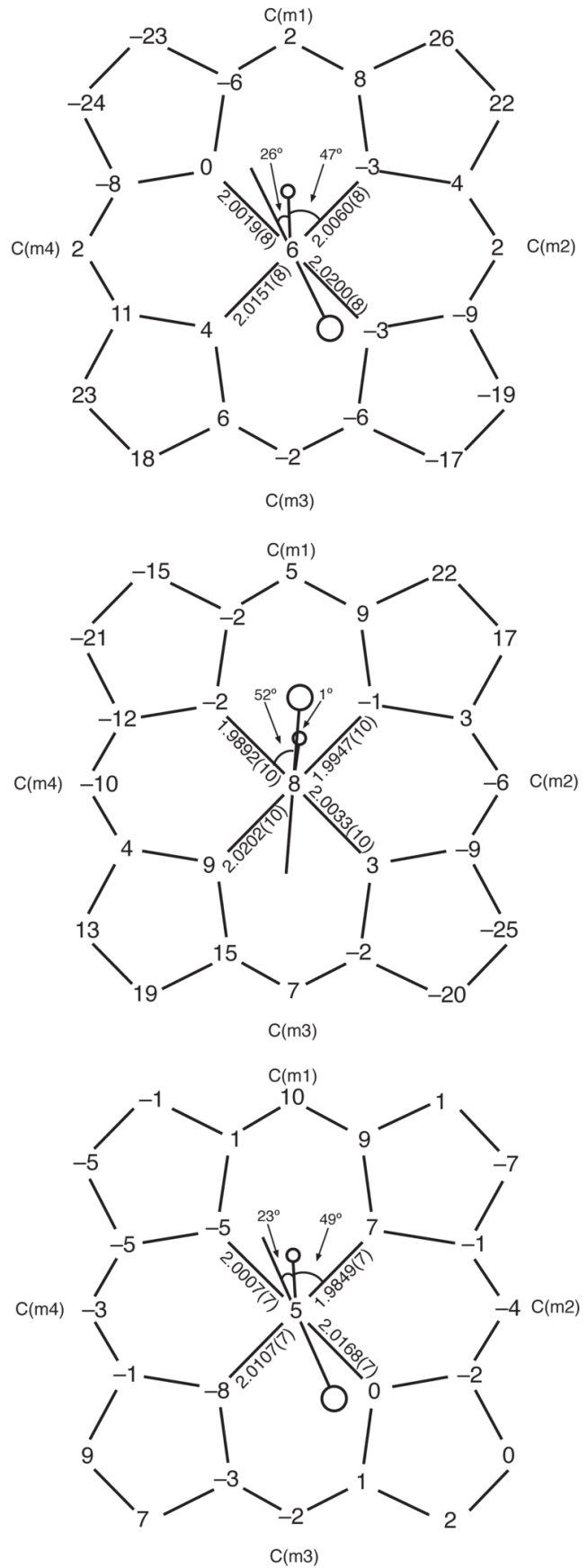

Figure 2.

Formal diagram of the porphyri-nato core of tri-[Fe(TpFPP)(1-MeIm)(NO)] (top), mono-[Fe $(\mathrm{T} p \mathrm{FPP})(1-\mathrm{MeIm})(\mathrm{NO})]$ (middle), and $\left[\mathrm{Fe}\left(\mathrm{T} p \mathrm{OCH}_{3} \mathrm{PP}\right)(\mathrm{NO})(1-\mathrm{MeIm})\right]($ bottom) at $100 \mathrm{~K}$ displaying the perpendicular displacements (in units of $0.01 \AA$ ) of the core atoms from the 24atom mean plane. Positive displacements are toward the nitrosyl-coordinated face, while the im-idazole ligand is displaced on the negative side of the porphyrin core. The orientation of the imidazole ligand with respect to the porphyrin core is also illustrated. The location of the 1-methyl group is represented by the large circle, while the location of the nitrosyl projection onto the porphyrin core is indicated by the small circle. $\mathrm{Fe}-\mathrm{N}_{\mathrm{p}}$ bond distances $(\AA)$ and angles (degrees) are also displayed. 


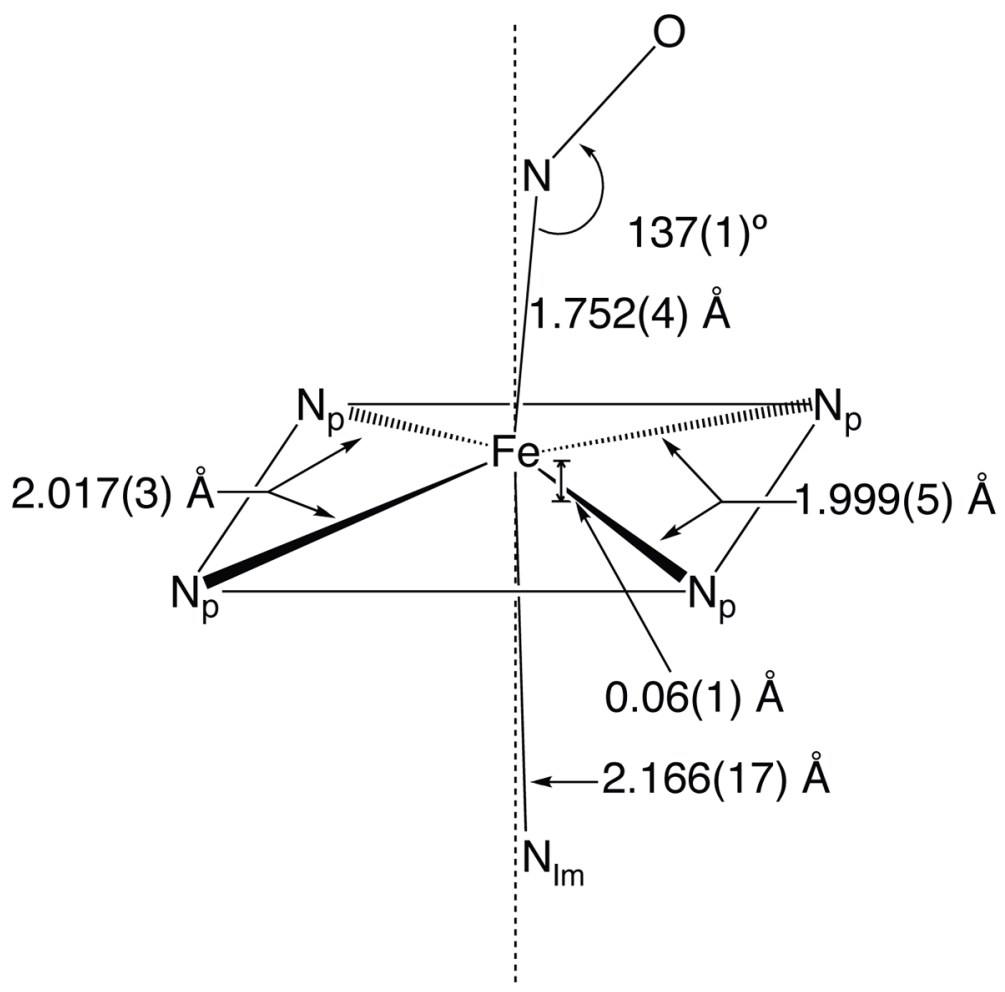

Figure 3.

Selected structural features of [Fe(Porph)(1-MeIm)(NO)] with standard deviations. Standard deviations are based on the five $100 \mathrm{~K}$ structures presented herein and two previous structure determinations 25,40 and the assumption that all are drawn from the same population. 


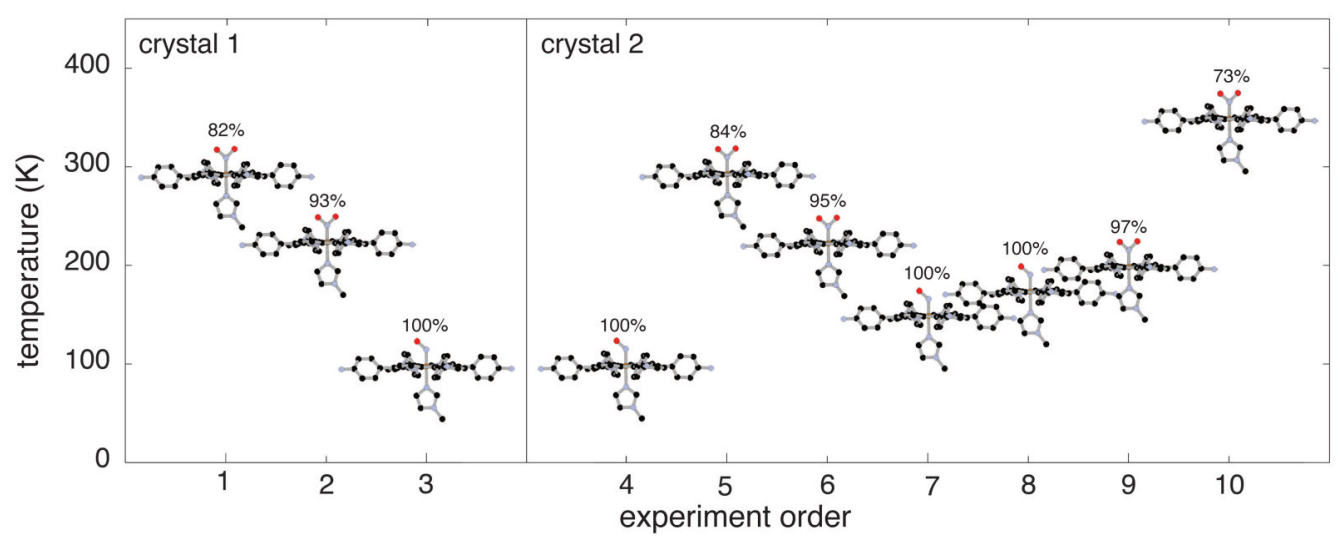

Figure 4.

Diagram displaying the order of data acquisition for $t r i$-[Fe(TpFPP)(NO)(1-MeIm)]. The temperature of data acquisition and occupancy factors for the major orientations are also displayed. 


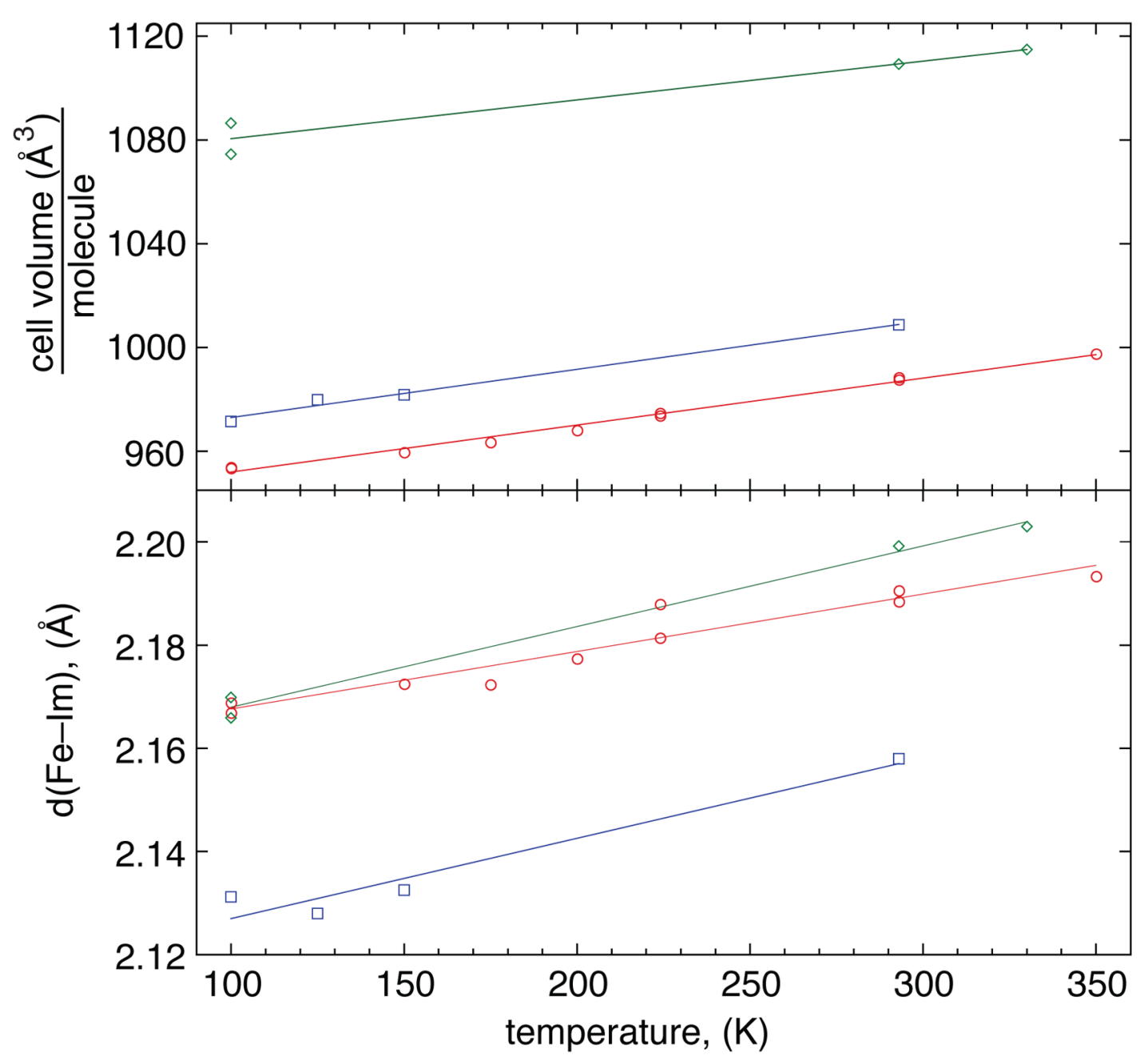

Figure 5.

Plot of cell volume per molecule $\left(\AA^{3}\right)$ or Fe-N $\mathrm{N}_{\text {Im }}$ bond distance $(\AA)$ vs. temperature $(\mathrm{K})$. Data illustrated are: (red circles) tri-[Fe(TpFPP)(NO)(1-MeIm)], (blue squares) mono-[Fe(TpFPP) (NO)(1-MeIm)], and (green diamonds) $\left[\mathrm{Fe}\left(\mathrm{T} p \mathrm{OCH}_{3} \mathrm{PP}\right)(\mathrm{NO})(1-\mathrm{MeIm})\right]$. Data points in each of the plots are fit linearly. Correlation coefficients for the top[bottom] plots are: tri-[Fe (TpFPP)(NO)(1-MeIm)] 0.99[0.96], mono-[Fe(TpFPP)(NO)(1-53 MeIm)] 0.99[0.97], and [Fe $\left.\left(\mathrm{T} p \mathrm{OCH}_{3} \mathrm{PP}\right)(\mathrm{NO})(1-\mathrm{MeIm})\right]$ 0.97[0.99]. 53 


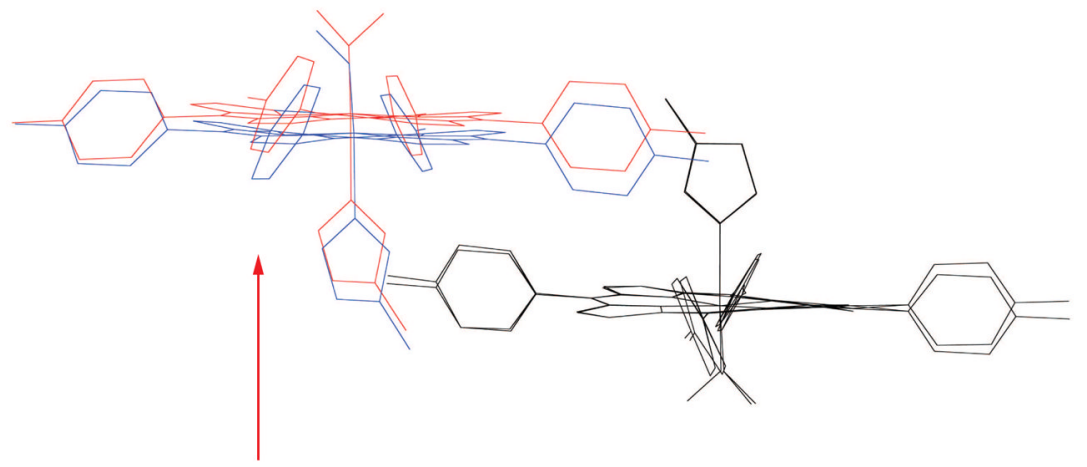

Figure 6.

An overlay diagram displaying the relative shift of adjacent molecules in the unit cell for tri$[\mathrm{Fe}(\mathrm{T} p \mathrm{FPP})(\mathrm{NO})(1-\mathrm{MeIm})]$ at $100 \mathrm{~K}$. The coordinates of the porphyrin nitrogen atoms of the 100 and $350 \mathrm{~K}$ structures have been overlaid for the two molecules shown at the bottom right. The relative differences in the intermolecular spacing of $\sim 0.5 \AA$ can now be seen between the $100 \mathrm{~K}$ structure (shown in blue) and the $350 \mathrm{~K}$ structure (shown in red). 


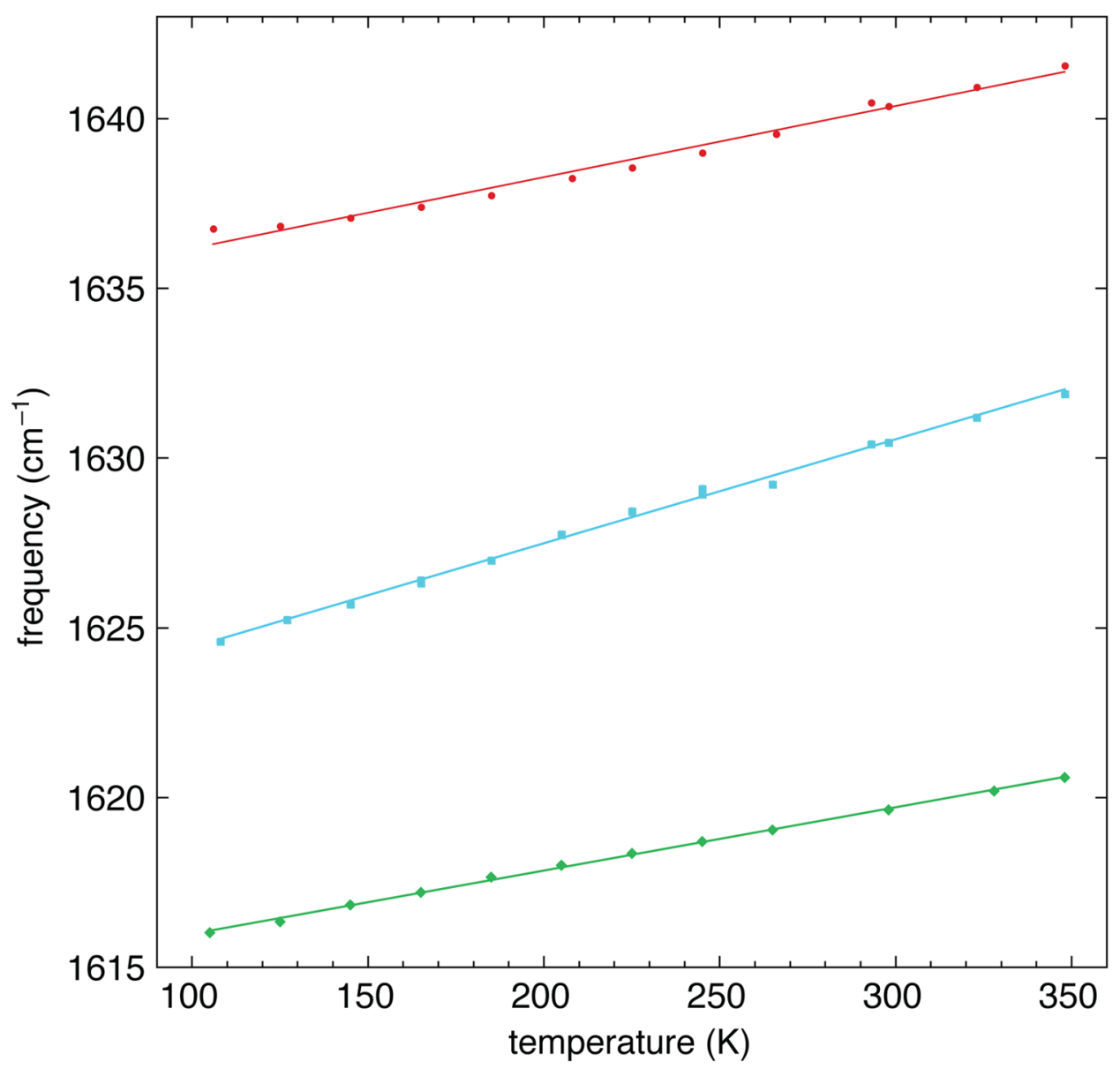

Figure 7.

Plot of $v_{\mathrm{N}-\mathrm{O}}\left(\mathrm{cm}^{-1}\right)$ vs. temperature $(\mathrm{K})$. Data illustrated are: tri-[Fe(TpFPP)(NO)(1-MeIm)] (red circles), mono-[Fe(TpFPP)(NO)(1-MeIm)] (blue squares) and $\left[\mathrm{Fe}\left(\mathrm{T} p \mathrm{OCH}_{3} \mathrm{PP}\right)(\mathrm{NO})(1-\right.$ $\mathrm{MeIm})$ ] (green diamonds). Each set of data points is fit linearly with correlation coefficients of $\mathrm{R}>0.99 .53$ 


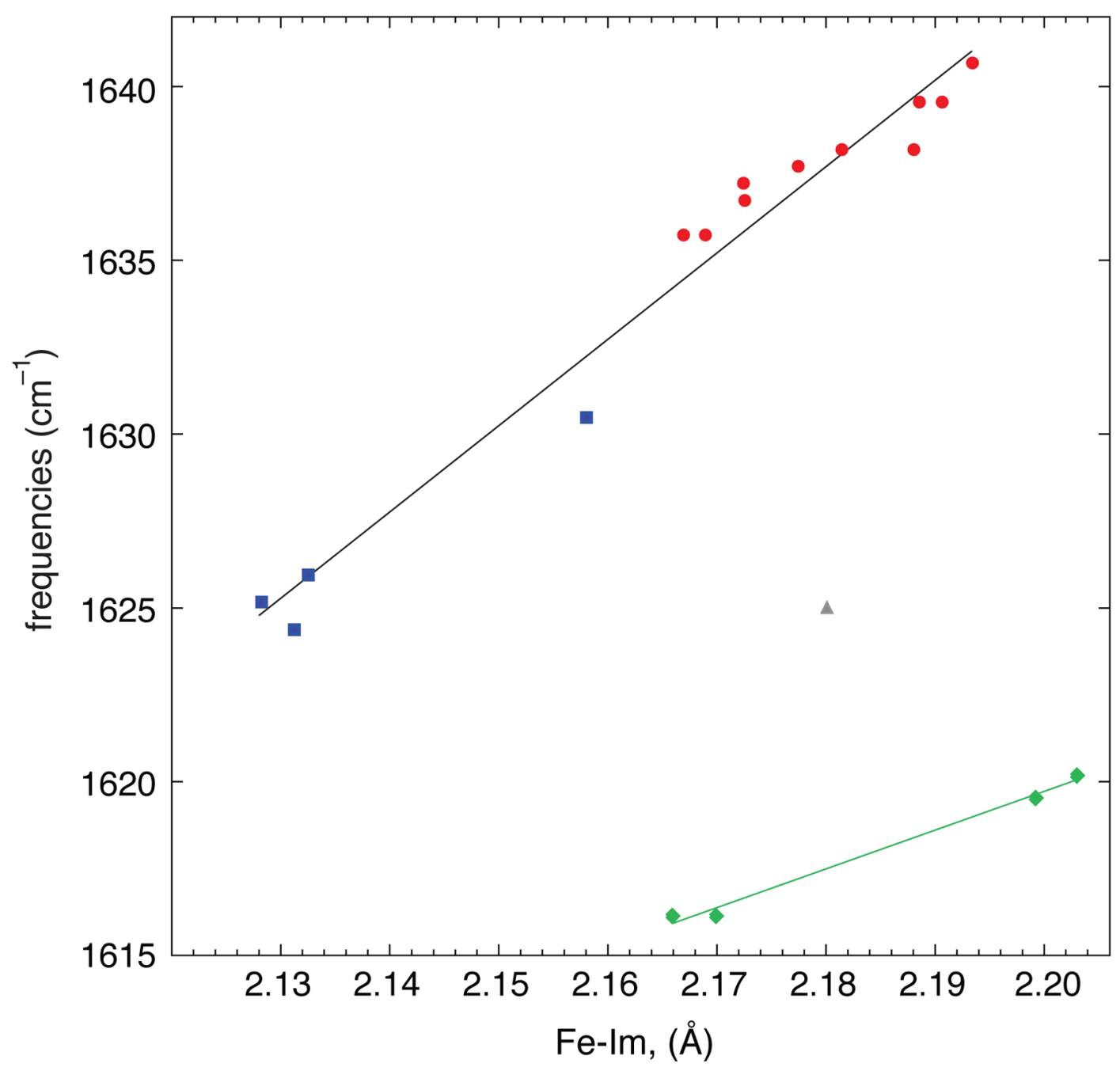

Figure 8.

Plot of $v_{\mathrm{N}-\mathrm{O}}\left(\mathrm{cm}^{-1}\right)$ vs. Fe-N $\mathrm{N}_{\text {Im }}$ bond distance $\left(\AA^{-1}\right)$. Data illustrated are triclinic (red circles) and monoclinic (blue squares) forms of [Fe(TpFPP)(NO)(1-MeIm)], [Fe(TpOCH $3 \mathrm{PP})(\mathrm{NO})(1-$ MeIm)] (green diamonds) and $[\mathrm{Fe}(\mathrm{TPP})(\mathrm{NO})(1-\mathrm{MeIm})]^{45}$ (grey triangle). Frequencies for a particular temperature are interpolated from the best fit line in Figure 7. Data points are fit with a correlation coefficient of $\mathrm{R}=0.98$ for $[\mathrm{Fe}(\mathrm{T} p \mathrm{FPP})(\mathrm{NO})(1-53 \mathrm{MeIm})]$ (black line) and $\mathrm{R}=$ 0.98 for $\left[\mathrm{Fe}\left(\mathrm{T} p \mathrm{OCH}_{3} \mathrm{PP}\right)(\mathrm{NO})(1-\mathrm{MeIm})\right]$ (green line) ${ }^{53}$ 


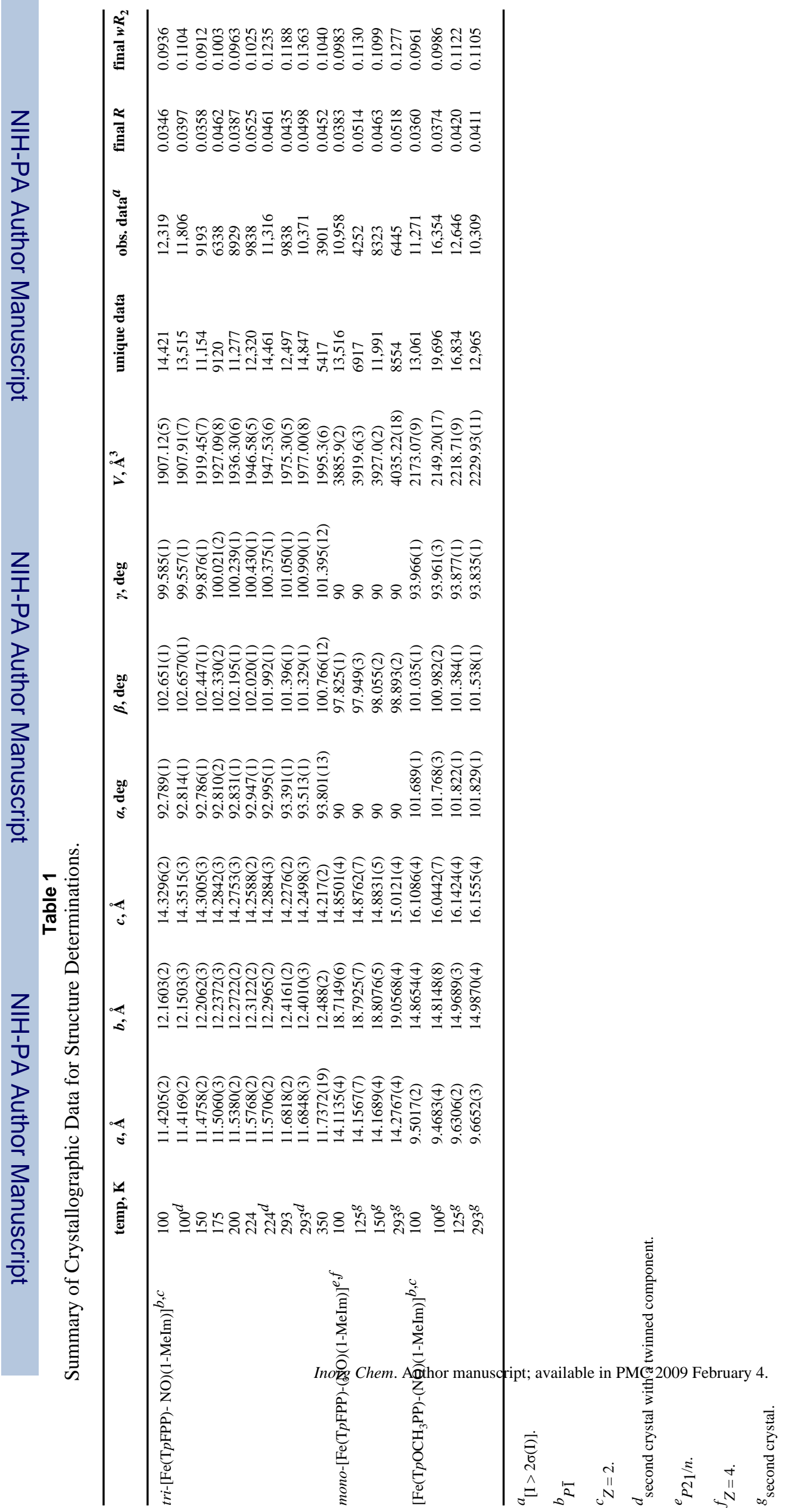




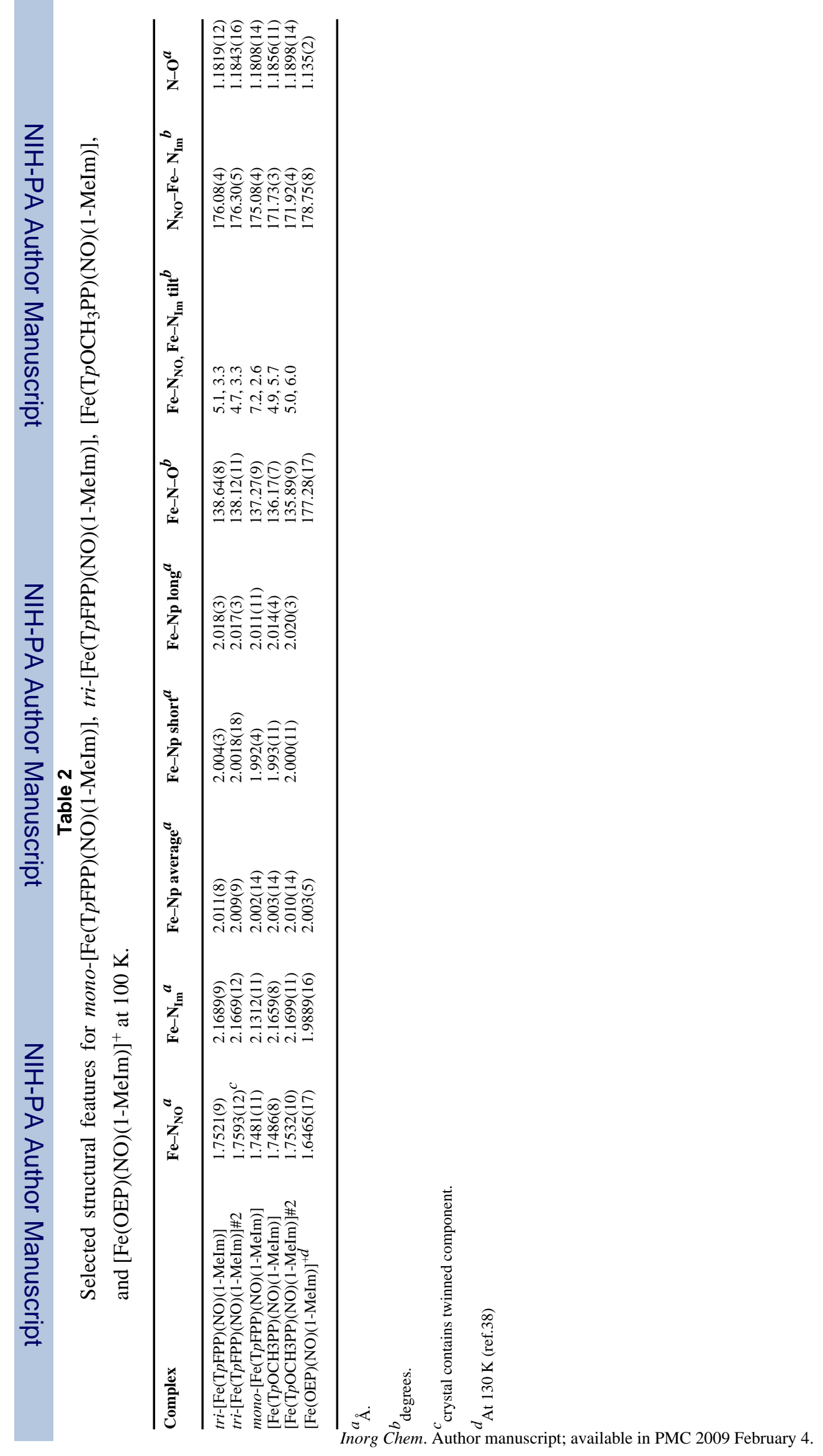




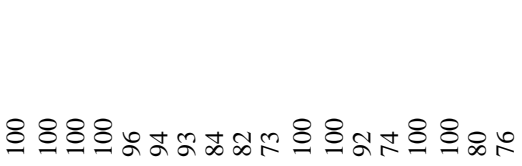

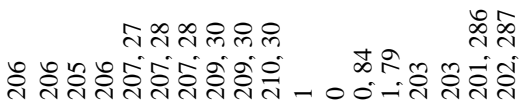

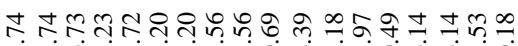

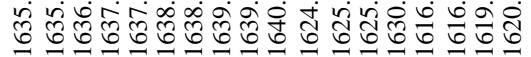

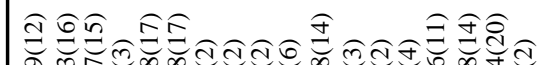

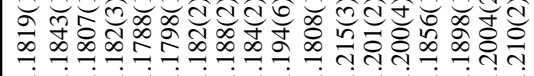

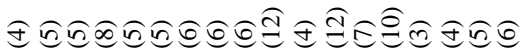

mo mo

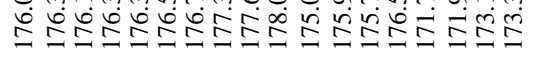

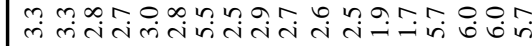

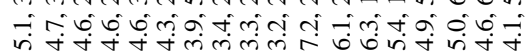

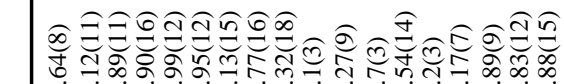

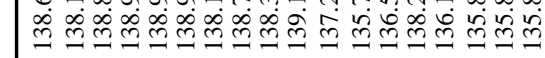

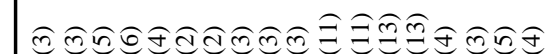

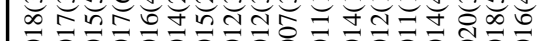

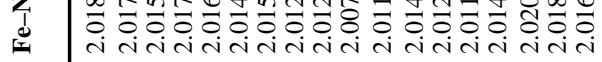


Table 4

Mössbauer data for six-coordinate [Fe(Porph)(1-MeIm)(NO)] complexes.

\begin{tabular}{|c|c|c|c|c|}
\hline Complex & $\mathbf{T}, \mathbf{K}$ & $\Delta E_{\mathrm{q}}, \mathrm{mm} / \mathrm{s}$ & $\delta, \mathrm{mm} / \mathrm{s}$ & ref \\
\hline \multirow[t]{6}{*}{ tri-[Fe(TpFPP)(1-MeIm)(NO)] } & 293 & 0.76 & 0.26 & tw \\
\hline & 250 & 0.75 & 0.29 & tw \\
\hline & 200 & 0.76 & 0.30 & tw \\
\hline & 150 & 0.76 & 0.32 & tw \\
\hline & 100 & 0.75 & 0.33 & tw \\
\hline & 20 & 0.74 & 0.34 & tw \\
\hline mono-[Fe(TpFPP)(1-MeIm)(NO)] & 293 & 0.75 & 0.22 & tw \\
\hline \multirow[t]{4}{*}[\mathrm{Fe}(\mathrm{T}p\mathrm{OCH}3\mathrm{PP})(1-\mathrm{MeIm})(\mathrm{NO})]{} & 293 & 0.87 & 0.24 & tw \\
\hline & 200 & 0.86 & 0.29 & tw \\
\hline & 100 & 0.84 & 0.32 & tw \\
\hline & 20 & 0.83 & 0.33 & tw \\
\hline \multirow[t]{4}{*}{ [Fe(TPP)(1-MeIm)(NO)] } & 293 & 0.80 & 0.24 & 25 \\
\hline & 150 & 0.75 & 0.31 & 25 \\
\hline & 50 & 0.75 & 0.33 & 25 \\
\hline & 4.2 & 0.73 & 0.35 & 25 \\
\hline
\end{tabular}

